\title{
DNA LOOPS AFTER CELL LYSIS RESEMBLE CHROMATIN LOOPS IN AN INTACT NUCLEUS
}

\author{
K. S. AFANASIEVA, V. V. OLEFIRENKO, A. V. SIVOLOB \\ ESC Institute of Biology and Medicine, \\ Taras Shevchenko National University of Kyiv, Ukraine; \\ e-mail: aphon@ukr.net
}

The comet assay has proved itself to be not only a method of detection of DNA damages at the level of individual cells but also an approach for investigation of spatial organization of DNA loop domains in nucleoids. Usually, those nucleoids are obtained after cell lysis in high-salt buffer (e. g. $2.5 \mathrm{M} \mathrm{NaCl)} \mathrm{with} \mathrm{a}$ detergent: these conditions ensure the removal of cell membranes and most of the chromatin proteins, while supercoiled DNA loop domains remain untouched. In this work, we tested the comet assay applied to nucleoids obtained in low-salt solution (1 M NaCl). These nucleoids keep most of the histones and thus contain the loops resembling the chromatin loops to a greater extent. It was shown that, despite some quantitative differences, the most general features of the kinetics of DNA exit are about the same for nucleoids obtained in high-and low-salt conditions. It can be concluded that the DNA loops in high-salt nucleoids can be efficiently used to investigate the spatial DNA organization in chromatin.

Keywords: DNA loop domains, cell lysis, nucleoids, comet assay.

$\mathrm{A}$ great breakthrough in the understanding of spatial chromatin organization that has been made in the last decade became possible owing to the development of new accurate research approaches and techniques. Among them, the most important are chromosome conformation capture (3C) and related methods that allow genomewide chromatin interaction mapping $[1,2]$. The comprehensive analysis of the interaction network makes it possible to describe the 3D architecture of the genome. The main advantages of these techniques arise from the possibility to get information, which reflects, to a large extent, chromatin structure in living cells - different improvements of original protocols presume minimum manipulation with cells that give an opportunity to retain intact chromatin structure [3].

Investigation of some aspects of DNA spatial organization in the cell nuclei is also possible due to an analysis of nucleoid structure $[4,5]$. The nucleoids are usually obtained after cell lysis with a low concentration of detergents and high ionic strength and consist of negatively supercoiled DNA loops at- tached to residual nuclear proteins that appear to be insensitive to the lysis conditions.

Single-cell gel electrophoresis (the comet assay) is a well-known technique which may be applied to investigate the nucleoids after the cell lysis [6-8]. The method is based on an analysis of DNA migration from nucleoids immobilized in a thin layer of agarose on microscopic slides. In our previous works $[7,9,10]$, measuring the kinetics of DNA exit during electrophoresis, we have shown that, in the case when intact undamaged cells are used for the lysis, the electrophoretic track (the comet tail) contains nothing but supercoiled DNA loops, which are extended to the anode. The exit of these loops occurs in two steps: the first rapid step corresponds to loops, migration of which is insensitive to supercoiling, whereas the migration at the second, delayed and cooperative, step is very sensitive to alteration of DNA supercoiling level. We have argued that the first rapid component should be composed of the loops located on the nucleoid surface while the second step represents the supercoiled loops inside the nucleoid [7].

(C) 2018 Afanasieva K. S. et al. This is an open-access article distributed under the terms of the Creative Commons Attribution License, which permits unrestricted use, distribution, and reproduction in any medium, provided the original author and source are credited. 
All these works were done using nucleoids obtained by the standard lysis procedure, i.e. cells immobilized in agarose were treated with low detergent concentration and $2.5 \mathrm{M} \mathrm{NaCl}$. The high salt concentration in the lysis solution ensures the total removal of histone proteins and most other chromatin proteins from DNA. The negative supercoiling of the nucleoid loops, mentioned above, is a direct consequence of the removal of nucleosomes from topologically constrained chromatin loop domains. We have suggested that the nucleoid DNA loops should resemble the chromatin loops. To check this assumption, we investigated the kinetics of DNA migration from nucleoids, which maintain most of the histone proteins thus containing the loops resembling, to a large extent, the chromatin loops. Our results show that the kinetics of the DNA exit, although being different quantitatively, keeps some important features observed earlier for nucleoids obtained by the standard lysis procedure. The results confirm the view that nucleoids (even those that were prepared in the standard way) can be used to investigate some peculiarities of the chromatin loop domain organization.

\section{Materials and Methods}

Sample preparation. Human peripheral blood (finger-prick samples) was obtained from healthy donors in the 20-35 age range (males and females, nonsmokers). Lymphocytes that were isolated by centrifugation in the density gradient Histopaque 1077 were washed with $0.15 \mathrm{M} \mathrm{NaCl}$ twice, and $50 \mu \mathrm{l}$ of the suspension was mixed with $100 \mu \mathrm{l}$ of $1 \%$ lowmelting-point agarose (Sigma, USA) at $\sim 37^{\circ} \mathrm{C} .25 \mu \mathrm{l}$ of the mixture was used to prepare a microscope slide, covered with $1 \%$ high-melting-point agarose. After agarose polymerization, the slides were immersed for several hours either in the standard lysis solution that contained $2.5 \mathrm{M} \mathrm{NaCl}, 100 \mathrm{MM}$ EDTA, $10 \mathrm{mM}$ Tris- $\mathrm{HCl}(\mathrm{pH} 8.0)$, and $1 \%$ Triton X-100 (high-salt buffer) or in the same solution with $1 \mathrm{M}$ $\mathrm{NaCl}$ (low-salt buffer) instead of $2.5 \mathrm{M}$. After the lysis, the slides were washed twice with TBE buffer (89 мM Tris-borate, 2 мM EDTA, pH 7.5).

Electrophoresis and microscopy. The slides were electrophoresised $(1 \mathrm{~V} / \mathrm{cm}, 300 \mathrm{~mA})$ at $4{ }^{\circ} \mathrm{C}$ in dark either in TBE buffer (the neutral comet assay) or in $300 \mathrm{mM} \mathrm{NaOH}, 1 \mathrm{mM}$ EDTA, $\mathrm{pH}>13$ (the alkaline comet assay). Before alkaline electrophoresis, the slides were incubated in the same alkaline buffer for $30 \mathrm{~min}$ at $4{ }^{\circ} \mathrm{C}$. After alkaline electrophoresis, the slides were neutralized by washing with TBE buffer.
To measure the kinetics of the comet formation, several slides (simultaneously prepared in the same way) were placed into the electrophoresis tank, and then they were taken out every $10 \mathrm{~min}$ of electrophoresis for further analysis. In some experiments, intercalator chloroquine was added to the electrophoretic buffer in different concentration. The concentration of chloroquine stock solutions was determined spectrophotometrically, taking the extinction coefficient $\varepsilon=14000 \mathrm{M}^{-1} \mathrm{~cm}^{-1}$ at $343 \mathrm{~nm}$.

After electrophoresis, the slides were stained with $1.3 \mu \mathrm{g} / \mathrm{ml}$ of DAPI (4',6-diamidino-2-phenylindole, Sigma, USA) and immediately analyzed with a fluorescent microscope (LOMO, Russia) connected with a camera Canon EOS $1000 \mathrm{D}$. The relative amount of DNA in the tails (as the ratio of the tail fluorescence intensity to the total intensity of the comet) was determined for 100-200 randomly chosen nucleoids per slide.

Analysis of the kinetic plots. Kinetic plots (the relative amount of DNA in the tail $f$ versus electrophoresis time $t$ ) were fitted with the equation $f=A_{1} f_{1}+A_{2} f_{2}$, where $A_{1}$ and $A_{2}$ are the maximum amplitudes of two components $\left(A_{2}\right.$ may be equal to 0 ). The function $f_{1}$ is described by a standard equation of monomolecular kinetics:

$$
f_{1}=1-\exp (-t / \tau)
$$

where $\tau$ is the characteristic time (the value that is inversely proportional to the rate constant $k_{1}$ ). The function $f_{2}$ obeys the sigmoidal Boltzmann equation:

$$
f_{2}=1 /\left[1+\exp \left(k_{2}\left(t_{0}-t\right)\right)\right],
$$

where $k_{2}$ is the rate constant, $t_{0}$ is the transition halftime.

\section{Results and Discussion}

Cell lysis in the high-salt buffer $(2.5 \mathrm{M} \mathrm{NaCl})$ ensures the total removal of histones and most of the other proteins from DNA. In the low-salt buffer (1 M $\mathrm{NaCl}$ ) most of non-histone proteins are removed, but nucleoids contain a mixture of nucleosome and subnucleosome particles bound to DNA: histone octamers (H2A-H2B-H3-H4), hexamers H2A-H2B$(\mathrm{H} 3-\mathrm{H} 4)_{2}$, and tetramers $(\mathrm{H} 3-\mathrm{H} 4)_{2}-$ about half of H2A-H2B dimers should be removed [11, 12].

A gallery of typical comets observed in fluorescent microscope after electrophoresis of nucleoids obtained in the low-salt conditions (referred to hereafter as low-salt nucleoids) is shown in Fig. 1. The appearance of the comets is about the same as 

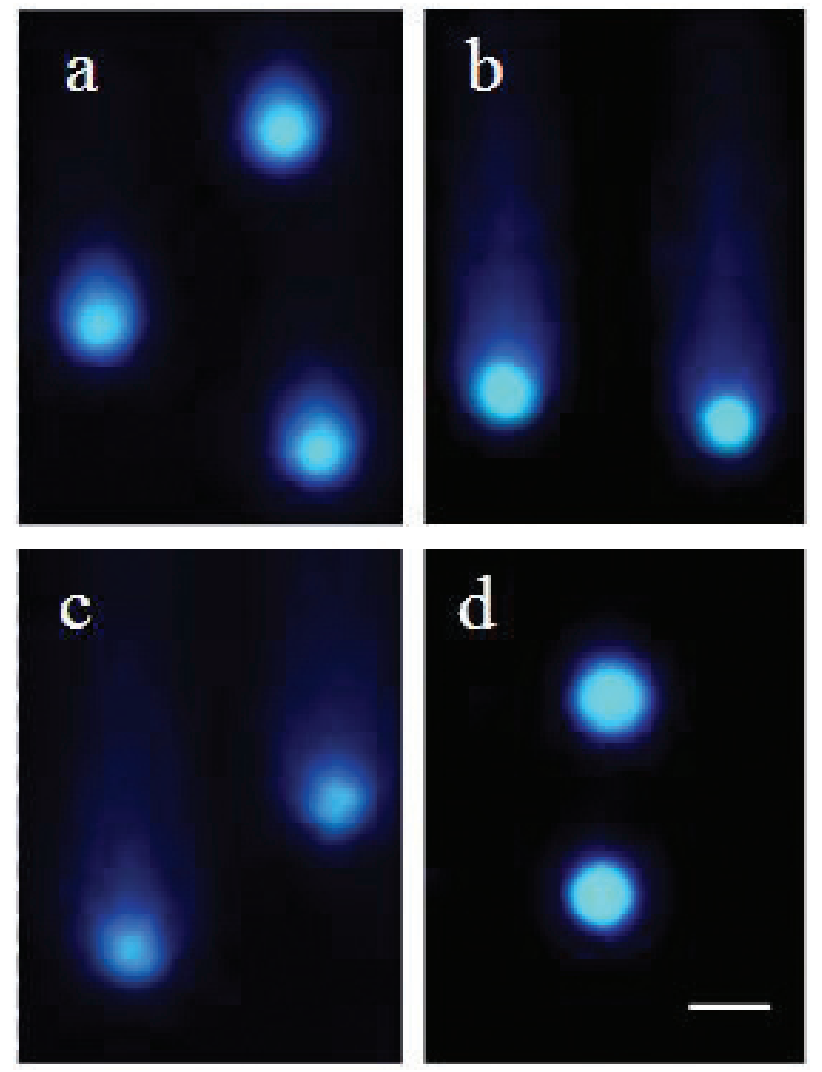

Fig. 1. The representative comet images of low-salt nucleoids after $20^{\text {th }}(\boldsymbol{a})$ and $120^{\text {th }}$ (b) min of electrophoresis in TBE buffer without intercalator and after $20^{\text {th }}$ and $120^{\text {th }}$ min of electrophoresis in the presence of chloroquine at the concentrations of 0.1 (c) and $1 \mu \mathrm{g} / \mathrm{ml}$ (d). Bars correspond to $10 \mu \mathrm{m}$

in our previous experiments with nucleoids obtained in high-salt buffer (high-salt nucleoids).

The kinetic plots of the average relative amount of DNA in the comet tail for the high-salt and lowsalt nucleoids resemble each other: both plots have a two-step shape (Fig. 2). The first rapid step that reflects the migration of small fraction of DNA was completely the same in the two cases with the maximum amplitude $A_{1}=0.07 \pm 0.01$ for both types of nucleoids and rate constants $k_{1}=0.12 \pm 0.05 \mathrm{~min}^{-1}$ and $k_{1}=0.15 \pm 0.08 \mathrm{~min}^{-1}$ for cells lysed in highsalt and low-salt solutions, respectively (Table 1). Despite the similarity of the first step, the DNA exit at the second delayed step had a few differences. First, the maximum amplitude $A_{2}$ of this step was almost three times lower for low-salt nucleoids than for nucleoids prepared by standard lysis procedure (Table 1) - the average amount of DNA in the comet tail after long-term electrophoresis (upper plateau of the kinetic curve) did not exceed $\sim 0.11$. Second,

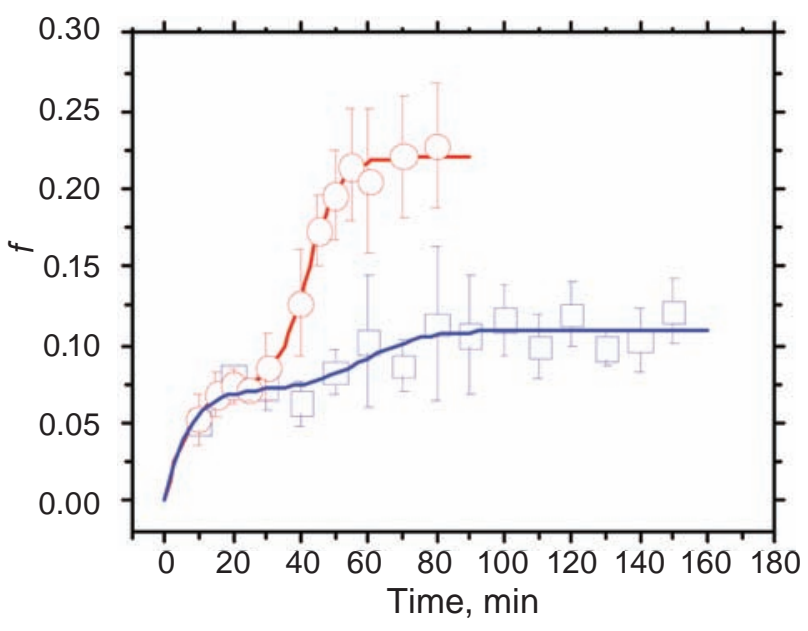

Fig. 2. The average relative amount of DNA in the comet tails (f) as a function of electrophoresis duration for high-salt (०) and low-salt () nucleoids. Here and in figures below the error bars represent the standard deviations

DNA migration appeared to be harder for these nucleoids with the rate constant $k_{2}=0.12 \pm 0.08 \mathrm{~min}^{-1}$ vs $k_{2}=0.22 \pm 0.08 \mathrm{~min}^{-1}$ for the high-salt nucleoids.

As we have shown in our previous work [7, 9], in the case of high-salt nucleoids the first rapid stage of DNA exit is achieved by migration to the anode of some DNA located at the nucleoid surface. In contrast to the loops that migrate at the second step, the rate of the first step is insensitive to the supercoiling level and to any disturbances in the loop anchor regions (i. e. different factors that can detach DNA loop ends from anchoring proteins) [7]. Considering the fact that at the first step DNA migration displays similar behavior for nucleoids of the two types, we

Table 1. The kinetic parameters of the DNA exit from high-salt and low-salt nucleoids

\begin{tabular}{c|c|c}
\hline Parameter & $\begin{array}{c}\text { High-salt } \\
\text { nucleoids }\end{array}$ & $\begin{array}{c}\text { Low-salt } \\
\text { nucleoids }\end{array}$ \\
\hline$A_{1}$ & $0.07 \pm 0.01$ & $0.07 \pm 0.01$ \\
$k_{1}\left(\mathrm{~min}^{-1}\right)$ & $7.8 \pm 2.9$ & $0.15 \pm 0.08$ \\
$A_{2}$ & $0.14 \pm 0.01$ & $0.04 \pm 0.01$ \\
$k_{2}\left(\mathrm{~min}^{-1}\right)$ & $0.22 \pm 0.08$ & $0.12 \pm 0.08$ \\
$t_{0}(\mathrm{~min})$ & $42.5 \pm 1.0$ & $58.5 \pm 9.2$ \\
\hline
\end{tabular}

$A_{1}$ and $A_{2}$ are the maximum amplitudes of two components of the kinetic plots; $k_{1}$ and $k_{2}$ are the rate constants of the first and second step of the kinetic plot, respectively; $t_{0}$ is the transition half-time for the second step. 


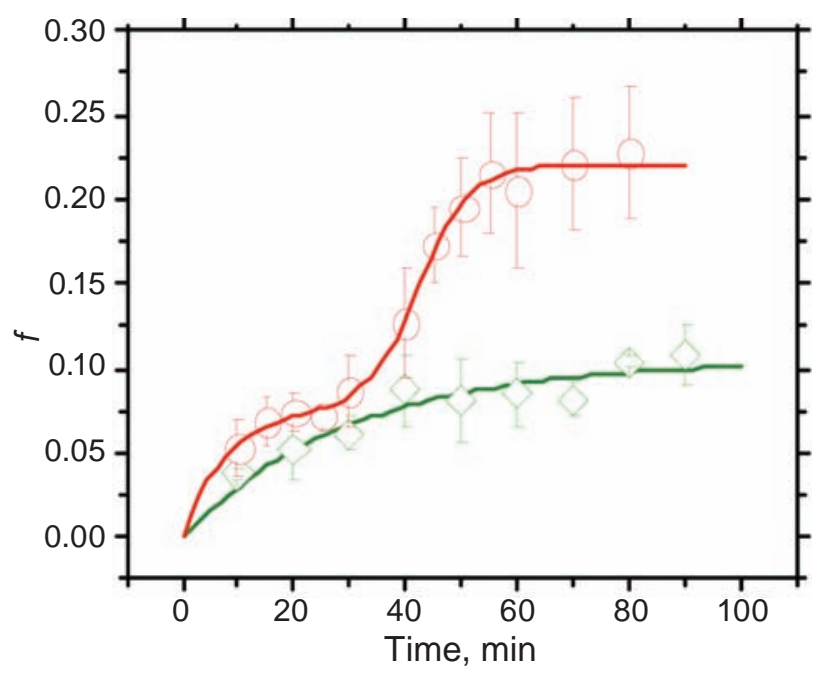

Fig. 3. The average relative amount of DNA in the comet tails $(f)$ after neutral $(0)$ and alkaline $(\diamond)$ electrophoresis of high-salt nucleoids

may conclude that the rapid component appears to be insensitive to lysis conditions too: effectiveness of DNA exit does not depend on the presence of nucleosomes in nucleoids.

Interestingly, under alkaline conditions, maximum DNA fraction in the comet tail for the high-salt nucleoids was almost at the same level as the first plateau formed under neutral conditions (Fig. 3). It was shown in numerous experiments that the key mechanism of the electrophoresis track formation

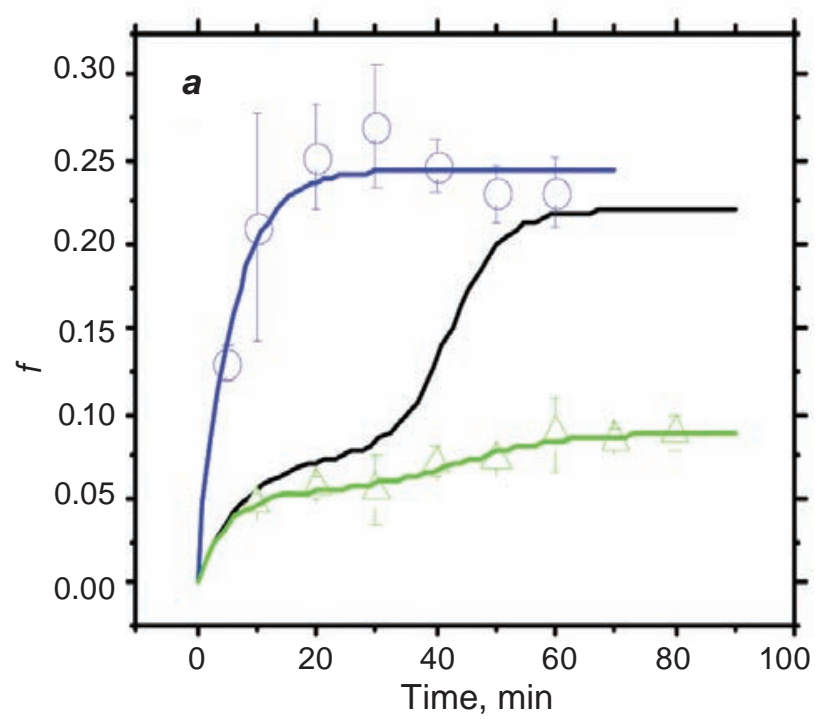

under alkaline conditions is the migration of singlestranded linear fragments resulted from multiple DNA single-strand breaks [13, 14]. Since the DNA amounts in the tails are almost the same in the alkaline comet assay and at the first step of the neutral assay, and also because of insensitivity of the first neutral step to the supercoiling, it can be assumed that under neutral conditions, the first step of DNA exit is mostly formed by loops that are relaxed due to nicks.

The second delayed step of DNA migration from the high-salt nucleoids was attributed to large supercoiled loops inside the nucleoid [7]. In contrast to the first step, DNA migration at the second step, as expected, is essentially hampered by nucleosomes: we observed both a slowdown in the DNA exit and a significant reduction of the maximum amount of DNA in the tails that can be reached after a long time of electrophoresis (Fig. 2, Table 1).

As it was mentioned above, the negative supercoiling appears in the loops of the high-salt nucleoids as a result of nucleosome removal. Since the lowsalt nucleoids still contain an essential part of nucleosomes and sub-nucleosomal particles, they should not be highly supercoiled. One may ask whether the loops that migrate at the second step from the lowsalt nucleoids are also under topological constraint.

An alteration of the topological state of DNA loops may occur due to intercalation of chloroquine.

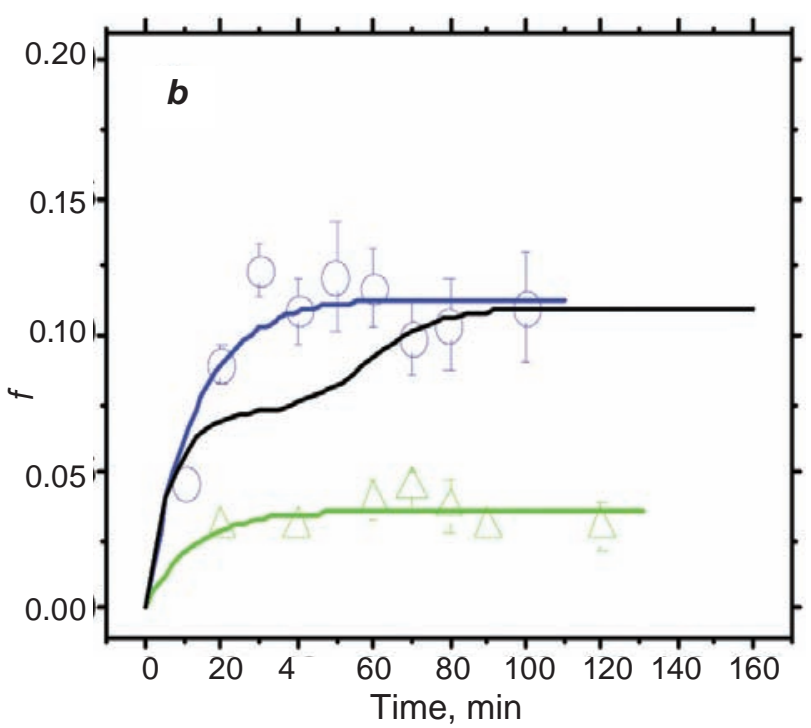

Fig. 4. Influence of chloroquine on the kinetics of DNA exit from high-salt (a) and low-salt (b) nucleoids. The chloroquine concentrations are $25 \mu \mathrm{g} / \mathrm{ml}$ (O) and $1000 \mu \mathrm{g} / \mathrm{ml}(\Delta)$ in panel a; $0.1 \mu \mathrm{g} / \mathrm{ml}$ (O) and $1 \mu \mathrm{g} / \mathrm{ml}(\Delta)$ in panel $\boldsymbol{b}$. The heavy curves are the continuous curves in the absence of chloroquine from Fig. 2 for two types of nucleoid 
For the high-salt nucleoids at some concentrations of chloroquine in the electrophoretic buffer (from 5 to $75 \mu \mathrm{g} / \mathrm{ml}$ ), due to relaxation of the negative supercoiling in the loops, an acceleration of the DNA exit was observed: the second step became as rapid as the first one. The maximum acceleration was observed at $25 \mu \mathrm{g} / \mathrm{ml}$ of chloroquine, the concentration, which approximately corresponds to the total relaxation of the negative supercoiling that appears after the nucleosome removal $[7,15]$ (Fig. 4, a). The same effect of the intercalator was observed for the low-salt nucleoids with the only difference that the DNA exit was significantly facilitated at very low chloroquine concentration $(0.1 \mu \mathrm{g} / \mathrm{ml})$ (Fig. $4, b)$. An increase in chloroquine concentration above the relaxation point induces a positive supercoiling in the loops that hampers their exit $[7,15]$. This effect was found to be the same for both types of nucleoids: an essential hampering was observed for the high- and low-salt nucleoids in $1000 \mu \mathrm{g} / \mathrm{ml}$ and $1 \mu \mathrm{g} / \mathrm{ml}$ of chloroquine, respectively (Fig. 4, $a, b$ ). Therefore, these results point out that: (i) the low-salt nucleoids contain the loops, which are topologically constrained; (ii) some very low level of negative supercoiling is present in these loops, which means that they really maintain the nucleosome organization to a large extent.

Altogether, our results allow us to make two conclusions. The first one is related to the nature of the first rapid stage of DNA migration during the neutral comet assay. The comparison of the kinetics of the comet formation for the high- and low-salt nucleoids, as well as for neutral and alkaline conditions, suggests that the first rapid step of DNA migration may be attributed to DNA loops with singlestrand breaks. Obviously, the DNA amount at this step increases, as it was shown in our earlier work [13], in the case of accumulation of DNA damages. The second, more important conclusion is based on the observation that the general behavior of the kinetics of DNA migration is the same for the highsalt, nucleosome-depleted nucleoids and low-salt nucleoids, which maintain the nucleosome organi- zation. It implies that the DNA loops in the high-salt nucleoids are the same as the chromatin loops and thus the comet assay can be efficiently used to investigate the spatial DNA organization in chromatin.

\section{ПІСЛЯ ЛІЗИСУ КЛІТИН ПЕТЕЛЬНІ ДОМЕНИ ДНК ЗБЕРІГАЮТЬ ОРГАНІЗАЦІЮ ХРОМАТИНОВИХ ПЕТЕЛЬ ІНТАКТНИХ ЯДЕР}

\author{
К. С. Афанасьєва, В. В. Олефіренко, \\ А. В. Сиволоб
ННЦ «Інститут біології та медицини», Київський національний університет імені Тараса Шевченка, Україна; e-mail: aphon@ukr.net

Кометний електрофорез виправдав себе не лише як метод детекції пошкоджень ДНК на рівні окремих клітин, але і як метод для дослідження просторової організації петельних доменів ДНК у нуклеоїдах. Зазвичай такі нуклеоїди одержують шляхом лізису клітин у високосольовому буфері $(2,5 \mathrm{M} \mathrm{NaCl})$ із детергентом: ці умови забезпечують видалення клітинних мембран та більшості хроматинових протеїнів, зберігаючи інтактними надспіралізовані петельні домени ДНК. У цій роботі ми здійснили кометний електрофорез нуклеоїдів, одержаних за низької концентрації солі (1 M NaCl). Такі нуклеоїди зберігають більшу частину гістонів і відповідно містять петлі значно більшою мірою схожі на нативні петлі хроматину. Показано, що, не дивлячись на кількісні відмінності, найбільш загальні властивості кінетики виходу ДНК із нуклеоїдів двох типів є подібними. Таким чином, петельні домени ДНК у нуклеоїдах, одержаних шляхом лізису клітин за високої іонної сили, можуть бути вдалою моделлю для дослідження просторової організації ДНК у хроматині.

К л ю ч о в і с ло в а: петельні домени ДНК, лізис клітин, нуклеоїд, кометний електрофорез. 


\section{ПОСЛЕ ЛИЗИСА КЛЕТОК \\ ПЕТЕЛЬНЫЕ ДОМЕНЫ ДНК \\ СОХРАНЯЮТ ОРГАНИЗАЦИЮ \\ ХРОМАТИНОВЫХ ПЕТЕЛЬ ИНТАКТНЫХ ЯДЕР}

\author{
К. С. Афанасьева, В. В. Олефиренко, \\ А. В. Сиволоб
УНЦ «Институт биологии и медицины», Киевский национальный университет имени Тараса Шевченко, Украина; e-mail: aphon@ukr.net

Кометный электрофорез оправдал себя не только как метод детекции повреждений ДНК в индивидуальных клетках, но и как метод для изучения пространственной организации петельных доменов ДНК нуклеоидов. Обычно такие нуклеоиды получают путем лизиса клеток в высокосолевом буфере $(2,5 \mathrm{M} \mathrm{NaCl})$ с детергентом: эти условия обеспечивают удаление клеточных мембран и большинства хроматиновых протеинов, сохраняя при этом интактными отрицательно сверхспирализованные петельные домены ДНК. В данной работе мы осуществили кометный электрофорез нуклеоидов, полученных при низкой концентрации соли $(1 \mathrm{M} \mathrm{NaCl})$. Такие нуклеоиды сохраняют большую часть гистонов и соответственно содержат петли в большей степени похожие на нативные петли хроматина. Показано, что, несмотря на количественные отличия, наиболее общие закономерности кинетики выхода ДНК из нуклеоидов обоих типов оказались схожими. Таким образом, петельные домены нуклеоидов, полученных путем лизиса клеток при высокой ионной силе, могут быть удачной моделью для исследования пространственной организации ДНК в хроматине.

К л ю че вы е с л о в а: петельные домены ДНК, лизис клеток, нуклеоид, кометный электрофорез.

\section{References}

1. Dekker J, Rippe K, Dekker M, Kleckner N. Capturing chromosome conformation. Science. 2002; 295(5558): 1306-1311.

2. Dekker J, Marti-Renom MA, Mirny LA. Exploring the three-dimensional organization of genomes: interpreting chromatin interaction data. Nat Rev Genet. 2013; 14(6): 390-403.

3. Rao SS, Huntley MH, Durand NC, Stamenova EK, Bochkov ID, Robinson JT, Sanborn AL, Machol I, Omer AD, Lander ES, Aiden EL. A 3D map of the human genome at kilobase resolution reveals principles of chromatin looping. Cell. 2014; 159(7): 16651680.

4. Cook PR, Brazell IA. Supercoils in human DNA. J Cell Sci. 1975; 19(2): 261-279.

5. Cook PR, Brazell IA, Jost E. Characterization of nuclear structures containing superhelical DNA. J Cell Sci. 1976; 22(2): 303-324.

6. Olive PL. The comet assay. An overview of techniques. Methods Mol Biol. 2002; 203: 179194.

7. Afanasieva K, Chopei M, Zazhytska M, Vikhreva M, Sivolob A. DNA loop domain organization as revealed by single-cell gel electrophoresis. Biochim Biophys Acta. 2013; 1833(12): 3237-3244.

8. Shaposhnikov S, El Yamani N, Collins AR. Fluorescent in situ hybridization on comets: FISH comet. Methods Mol Biol. 2015; 1288: 363373.

9. Afanasieva K, Chopei M, Sivolob A. Single nucleus versus single-cell gel electrophoresis: kinetics of DNA track formation. Electrophoresis. 2015; 36(7-8): 973-977.

10. Afanasieva K, Chopei M, Lozovik A, Semenova A, Lukash L, Sivolob A. DNA loop domain organization in nucleoids from cells of different types. Biochem Biophys Res Commun. 2017; 483(1): 142-146. 
11. Eickbush TH, Moudrianakis EN. The histone core complex: an octamer assembled by two sets of protein-protein interactions. Biochemistry. 1978; 17(23): 4955-4964.

12. Khrapunov SN, Dragan AI, Sivolob AV, Zagariya AM. Mechanisms of stabilizing nucleosome structure. Study of dissociation of histone octamer from DNA. Biochim Biophys Acta. 1997; 1351(1-2): 213-222.

13. Afanasieva K, Zazhytska M, Sivolob A. Kinetics of comet formation in single-cell gel electrophoresis: loops and fragments. Electrophoresis. 2010; 31(3): 512-519.
14. Møller P. The alkaline comet assay: towards validation in biomonitoring of DNA damaging exposures. Basic Clin Pharmacol Toxicol. 2006; 98(4): 336-345.

15. Zazhytska MO, Afanasieva KS, Chopei MI, Vikhreva MA, Sivolob AV. Influence of chloroquine on kinetics of single-cell gel electrophoresis. Biopolym Cell. 2012; 28(4): 291297.

Received 24.05.2018 